\title{
IDENTITAS DAN PERLAWANAN SEORANG BURONAN DALAM \\ KONFLIK ACEH: MENJELAJAHI TANAH SURGA MERAH KARYA ARAFAT NUR
}

\author{
Yusri Fajar ${ }^{1}$ \\ ${ }^{1}$ Universitas Brawijaya, yusri_fajar@ub.ac.id
}

\begin{abstract}
ABSTRAK
Berbagai persoalan dalam sejarah Aceh bersemayam dalam dunia kreatif novelis Arafat Nur, termasuk novel Surga Tanah Merah, yang lebih membuka mata pembaca pada konflik yang terjadi antar sesama orang Aceh di era sekarang. Dalam makalah ini, saya menguraikan bagaimana Arafat Nur menghadirkan identitas hibrid yang ambigu melalui sosok Murad, seorang pahlawan yang sekaligus buronan. Di satu sisi, Murad adalah seseorang yang dirayakan sebagai pahlawan karena dianggap memperjuangkan kemerdekaan Aceh dari penjajahan pemerintah pusat Indonesia. Namun, dalam narasi novel, Murad sudah menjadi buronan dari pemerintah pusat dan orang-orang Aceh yang ingin menghabisinya. Memori masa lalu ini berdialektika dengan kondisi Murad saat ini, menghasilkan keterasingan yang mengkonstruksi identitas Murad. Dengan narasi seperti ini, Surga Tanah Merah menyodorkan kritik bagi Aceh yang disertai harapan akan kesejarahteraan dan kedamaian.
\end{abstract}

Aceh dalam narasi sejarah Indonesia selalu membangkitkan memori tentang pergolakan dan perlawanan. Identitas Aceh di masa lalu dikenal sebagai daerah yang tak mudah ditaklukkan oleh Belanda di masa penjajahan. Di masa pascakolonial selepas dari cengkeraman Belanda, Aceh juga tak mudah dikontrol oleh pemerintah pusat. Kelompok 'Gerakan Aceh Merdeka' terus melakukan perlawanan terhadap penjajahan yang dilakukan pemerintah. Bumi berjuluk 'Serambi Mekkah', namun juga dikenal sebagai daerah ladang subur ganja ini, pernah menjadi daerah operasi militer (DOM) di era orde baru. Bahkan setelah perjanjian damai, Aceh masih dalam bayang-bayang kecamuk pertikaian. Berbagai peristiwa ini bersemayam dalam dunia kreatif novelis Arafat Nur, yang dalam novelnovelnya selalu menyuguhkan lanskap konflik Aceh. Tokoh-tokoh beridentitas kultural Aceh berada dalam pusaran konflik yang mengharuskan mereka menegosiasikan, mentransformasikan identitas mereka, serta melakukan perlawanan terhadap hegemoni pemerintah. Novel-novel Arafat Nur, mulai "Lampuki" (pemenang penghargaan Kusala Sastra Khatulistiwa 2011), "Burung Terbang di Malam Kelam” (2014), hingga "Tanah Surga Merah" (2016, pemenang unggulan sayembara novel DKJ, diterbitkan Gramedia), memang memiliki benang merah sebagai novel yang mengungkapkan konflik horisontal di Aceh. Ruang kreatif Arafat Nur diwarnai konstelasi sejarah dan pergolakan politik Aceh yang bersemayam di alam pikiran banyak generasi bangsa, sehingga narasi-narasi dalam novel ini bukan semata imaji yang hampa.

Meskipun melalui novel "Surga Tanah Merah" Arafat Nur menarasikan suara-suara perlawanan terhadap 'penjajah', untuk menyebut pihak yang menghegemomi Aceh di era sebelum dan pasca perjanjian perdamaian GAM dan Pemerintah, Arafat Nur sesungguhnya tidak sedang mengajak dan menggugah kita untuk melafalkan narasi sastra perang seperti Hikayat Perang Sabil sebagai pelecut untuk melawan penjajah dengan bertempur langsung setelah hikayat tersebut dibacakan di rumah, di dayah-dayah (pesantren), dan meunasah- 
meunasah (surau-surau) pada masa pendudukan penjajah Belanda di Aceh. Arafat Nur lebih membuka mata pembaca pada konflik yang terjadi antar sesama orang-orang Aceh di era sekarang, dan melakukan kritik tajam terhadap para elite baru Aceh yang lupa tujuan mulia perjuangan ketika mereka dulu tergabung dalam Gerakan Aceh Merdeka. Rasanya menarik jika bisa mendengar tanggapan para pemanggul amanah dalam pemerintah Aceh sekarang jika mereka sudah membaca novel "Surga Tanah Merah". Dulu Hikayat Perang Sabil begitu ditakuti oleh pemerintah Hindia Belanda sehingga hikayat-hikayat perang sabil ini disita karena membangkitkan kesadaran rakyat Aceh untuk mengangkat senjata (Alfian, 2003:181). Lalu apakah novel beraroma kritik politik dan konflik Aceh ini ketika selesai dibaca akan juga disita karena dikhawatirkan membangkitkan kewarasan berpikir untuk melawan tirani? Di era keterbukaan ini novel Arafat Nur tentu tak perlu dikhawatirkan karena novel ini justru bisa menjadi medium berkaca diri dan melakukan kritik demi Aceh yang lebih baik. Dalam perspektif sosiologi sastra, pada konteks ini kita bisa mempertanyakan, sebagaimana disinggung Faruk, sejauh mana sastra berfungsi sebagai perombak masyarakatnya (2010:5). Apakah novel "Surga Tanah Merah" dengan muatan kritik tajamnya tentang kondisi Aceh bisa meneteskan embun kesadaran bagi elite Aceh untuk melakukan perubahan yang lebih baik? Tak mudah untuk menjawab pertanyaan ini, karena karya sastra berperan dalam perubahan secara tidak langsung, namun bisa menjadi medium intropeksi dan pembangkit kesadaran untuk perubahan.

"Tanah Surga Merah" digerakkan melalui narator utama bernama Murad yang merupakan seorang bekas anggota GAM yang terlibat konflik dengan kawan-kawannya, yang kini menduduki jabatan-jabatan penting dalam pemerintahan Aceh. Di tangan Arafat Nur, identitas Murad sebagai pelarian politik Aceh menjadi sangat kompleks, dinamis dan hibrid. Konstruksi identitas Murad dipengaruhi oleh berbagai faktor di luar diri sang pelarian, mulai politik, budaya dan agama. Sebagaimana dikatakan oleh Hall, identitas bukanlah sesuatu yang natural melainkan hasil konstruksi, selalu mengalami transformasi dan dengan mengutip pendapat Laclau dan Bhabha, Hall lebih jauh menegaskan bahwa identitas terkonstruksi dalam permainan kekuasaan dan pembatasan (1996:5). Arafat Nur menyajikan pada kita melalui novel 'Tanah Surga Merah' tentang bagaimana Murad tersingkir dan terasing dari pusat kekuasaan lokal Aceh, hingga dia teralineasi dan diburu, 5 tahun lebih hidup dalam pelarian di luar Aceh. Dalam eskalasi sosial dan historis yang begitu dinamis, penuh fragmentasi dan polarisasi, identitas Murad mengalami perubahan-perubahan mulai secara fisik, politik, religius dan kultural karena situasi konflik Aceh yang tegang dan penuh kecurigaan. Sementara, dalam pelarian dan persembunyiannya hingga ia muncul kembali di Aceh, Murad tak habis-habis mengkritik penguasa lokal Aceh, seakan terus melakukan perlawanan. Oleh karena itu, novel "Surga Tanah Merah" bagi saya merupakan medium Arafat Nur sebagai penulis dari Aceh, untuk mengekspresikan pandangan, tanggapan dan pemikiran kritisnya tentang kondisi Aceh dulu dan sekarang.

\section{KONSTRUKSI IDENTITAS MURAD}

Sebelum lari dari Aceh, Murad menyandang identitas sebagai pahlawan karena dianggap memperjuangkan kemerdekaan Aceh dari penjajahan pemerintah pusat Indonesia. Identitas pahlawan ini bisa dipandang sebagai penghargaan dan penghormatan sebagian 
warga Aceh atas perjuangan yang dilakukan Murad untuk meraih 'kedaulatan' dan 'otonomi' Aceh.

Sebelum tuntutan peristiwa yang menyebabkan aku harus melarikan diri dan bersembunyi di tempat yang asing, tidak lama setelah kesepakatan damai dimulai, aku adalah pejuang kemerdekaan bersama tiga ratus lebih pejuang lain yang dipujapuji, ditakuti, dan juga disegani banyak orang. Sekarang arah telah berbalik tajam, aku bukan lagi pahlawan, melainkan penjahat buronan yang diintai polisi dan diburu oleh orang-orang Partai Merah yang menaruh dendam kesumat (Arafat Nur, 2016: 10)

Arafat Nur membangun identitas hibrid yang ambigu: pahlawan dan buronan. Di satu sisi Murad pernah dianggap sebagai pejuang yang dielu-elukan masyarakat Aceh yang merindukan kebebasan dari cengkeraman 'penjajah'. Di sisi lainnya Murad menjadi sosok yang diburu dan distereotipkan negatif, sebagai buronan. Konstruksi identitas pahlawan dan buronan serta orang yang dianggap pecundang, dengan demikian, sangat ditentukan oleh cara pandang masyarakat yang bisa saja mengalami polarisasi dalam memandang seseorang.

Murad berada dalam memori masa lalu dan masa kini. Ia seperti berusaha menyatukan kembali kepingan-kepingan romantika masa lalu dan menemukan kembali harihari indah yang sebelumnya hilang dari hidupnya. Narasi Arafat Nur ini mengingatkan saya pada kisah-kisah orang-orang yang harus pergi dari kampung halamannya karena pergolakan politik seperti yang dikisahkan penulis keturunan India, Salman Rusdhi, dalam bukunya yang bertajuk Imaginary Homeland (1992); Ingatan orang-orang yang keluar dari teritori kampung halamannya bagi Rushdi selalu mengalami fragmentasi, tak mudah bagi mereka untuk menyatukan kembali ingatan-ingatannya tentang kampung halaman karena telah lama tinggal di teritori lain, sebagaimana yang dialami Murad yang selalu menyemaikan kerinduannya pada kampung halamannya demi merawat kecintaannya. Kepulangan Murad ke Aceh dari pelariannya mencerminkan gelora dalam diri Murad untuk menapaktilasi kembali kenangan dan meneguhkan kembali identitasnya sebagai putra Aceh.

Dialektika masa lalu dan masa kini serta sikap yang ditunjukkan Murad dalam "Surga Tanah Merah" dalam merespon dialektika tersebut menjadi sumber pembentuk identitas Murad, sebagai generasi Aceh yang mencintai Aceh, namun mengkritik dan memprotes keras hegemoni para elite lokal baru, para pemimpin Partai Merah, yang ingin menyingkirkannya. Meskipun Murad adalah lelaki asli Aceh, dia oleh para elite aceh dianggap 'sang liyan' (the other), terutama oleh elite partai merah. Bahkan Murad merasa asing dengan dirinya sendiri.

Perasaan terasing yang dialami Murad pada dasarnya disebabkan perbedaan antara identitas terdahulu dan identitas sekarang. Terbentang jurang menganga di antara keduanya yang membuat Murad tak mudah menjembataninya. Keterasingan Murad lebih jauh juga disebabkan kondisi di mana dia harus menjadi pelarian selama lima tahun lebih dan tak lagi bisa mengikuti perkembangan daerahnya selama dalam pelariannya. Dia terpisah dari kampung halaman dan berbagai praktik sosial kultural keagamaan di Aceh. Setelah kembali ia harus beradaptasi kembali:

Tiba-tiba saja aku merasa asing pada tanah kelahiranku yang pulang ke rumah sendiri pun harus diam-diam dan sembunyi-sembunyi seperti pencuri. Orang-orang dekat dan 
sahabat karib kini menjadi musuh, bahkan mereka hendak membunuhku. Sementara aku harus menjauhi keluarga dan teman-teman dekat yang tidak terlibat politik. Sungguh asing rasanya negeri ini, tapi aku terlanjur tidak bisa hidup di tempat lain. Tanah ini rumahku, surgaku; surga tanah merah (Arafat Nur, 2016: 129)

Perasaan terasing Murad pada dasarnya juga disebabkan penolakan beberapa orang Aceh atas kehadirannya. Teman dan sahabat dekat telah mengambil posisi berkonfrontasi dengannya. Konstalasi politik Aceh yang membuat Murad menjadi pelarian telah menciptakan jarak antara Murad dan kampung halamannya serta keluarga serta temantemannya. Kedekatan dan sosialisasi sebagai prasyarat menjalani hidup secara nyaman dan bersama-sama tak bisa Murad dapatkan lagi seperti sedia kala. Kondisi-kondisi yang membuatnya tak memiliki akses leluasa pada kampung halamannya dan keterbatasan berkomunikasi dengan teman-temannya di Aceh mengantarkan Murad dalam perasaan terasing dari hari demi hari.

Perubahan identitas ini disadari Murad sebagai strategi untuk menghadapi tindakan represif dan melakukan penetrasi ke kampung halamannya, beradaptasi dan berharap untuk berjuang kembali mewujudkan idealismenya. Perubahan identitas fisik Murad dikisahkan Arafat Nur sebagai cara yang dipilih oleh Murad untuk menyelamatkan diri dari perburuan orang-orang yang akan menghabisi Murad. Orang-orang dari Partai Merah memusuhi dan ingin menyingkirkan Murad. Sebelumnya Murad dikenal dari nama dan ciri-ciri fisiknya seperti cambang dan jenggot:

"Akhirnya aku terpaksa merontokkan cambang, janggut, dan mengubah nama, sehingga mereka sulit untuk menemukanku" (Arafat Nur, 2016:27)

Murad secara fisik memang berubah. Tampangnya tidak lagi seperti ketika dia menjadi gerilyawan Gerakan Aceh Merdeka, namun sesungguhnya semangat dan prinsip perjuangannya untuk kemajuan Aceh tak pernah padam dan berubah.

Sementara Konstruksi identitas politik Murad dibangun Arafat Nur secara dinamis dan dialektis yaitu melalui konflik horisontal di Aceh, yang melibatkan GAM dan pemerintah. Murod menjadi bagian dari pejuang yang bergerilya di hutan. Identitas yang terkait kemampuan Murad beradaptasi dengan medan sulit dan hidup berkesusahan telah terbentuk sejak dia menjadi pejuang.

"Aku hanya seorang tentara gerilya yang menjabat Wakil Panglima Sagoe merangkat juru bicara dan beberapa kali sempat menulis artikel di surat kabar lokal dengan nama samaran, yang semuanya berupa gagasan pentingnya mendirikan Partai Jingga" (Arafat Nur, 2016: 14)

Jabatan Murad merupakan jabatan politis dan strategis dalam GAM. Ia juga dicitrakan Arafat Nur sebagai buronan yang memiliki kompetensi intelektual. Salah satu indikasinya adalah kemampuan Murad dalam menyampaikan gagasannya di media massa lokal. Tanpa kemampuan berpikir yang kritis, tak mungkin Murad mampu menyampaikan tulisan-tulisan propagandanya di media massa. Kita bisa membaca bahwa keterlibatan Murad dalam dunia gerilya dan orientasi politiknya telah membentuk jati dirinya. Latar dan orientasi ini pada dasarnya tidak terlepas dari keinginan Murad untuk memperjuangkan kemajuan bumi Aceh. 
Gagasan mendirikan partai Jingga menunjukkan cara dan strategi perjuangan politik yang ingin dijalankan Murad.

Sebelumnya, dalam paparan Arafat Nur, Murad sebenarnya pernah bergabung dengan partai Merah Aceh, namun karena tidak puas maka dia keluar dan sempat juga terlibat dalam partai yang dianggap kecil, yaitu partai Jingga. Dia menilai banyak politisi partai merah yang tak lagi memperjuangkan rakyat Aceh. Cita-cita perjuangan mulia partai telah diselewengkan. Mereka lebih senang menimbun keuntungan pribadi dan untuk partai. Identitas Murad juga dikenal sebagai orang yang tak kenal kompromi dengan tindakan asusila dan bertentangan dengan prinsip perjuangan. Murad adalah juga pejuang yang tegas dalam membela kebenaran. Ia misalnya menembak mati seorang Aceh yang hendak memerkosa seorang gadis Aceh. Hal ini menunjukkan Murad tak mau berkompromi dengan tindakan yang dia pandang sebagai kejahatan dan merendahkan martabat serta harga diri warga Aceh.

Hal menarik terkait identitas religius dan kultural yang dinarasikan Arafat Nur dalam "Surga Tanah Merah" adalah perubahan identitas Murad yang dulu dikenal pejuang kemerdekaan Aceh, politisi seperti yang saya bahas di atas, kemudian setelah diburu sepulang dia dari pelarian, kemudian bersembunyi lagi di padalaman Aceh, dia berubah identitas sebagai seorang Teungku (yang sebenarnya dia merasa tak pantas menyandangnya). Demi keamanan Murad dari perburuan orang-orang partai Merah, sahabat Murad yang bernama Imran mengirim Murad ke suatu daerah di pedalaman yang sangat jauh dan sulit dijagkau. Imran juga mengubah nama Murad menjadi nama yang identik dengan tokoh agama: “ Sekarang kau bukan lagi Murad, tapi kau Teungku Ghafar Sabi.” (Arafat Nur, 2016:191) Tentu saja identitas baru yang disandang oleh Murad membuat Murad tidak nyaman dan cenderung ingin melepas identitas tersebut. Namun Murad tak bisa menghindar dan menolak. Perubahan identitas ini harus dilakukan karena konstelasi politik dan keamanan serta sebagai upaya membaurkan masyarakat desa Klekklok dengan Murad:

"Saudara-saudara! Ini adalah Teungku Ghafar Sabi, pandai agama yang dikirimkan pemerintah kemari!" teriak Dahli pada sekalian orang yang membuat perutku mual. "Kalian perlu belajar agama dan semoga Allah melindungi kalian semua dari bencana Alam dan petaka dunia!" (Arafat Nur, 2016: 201)

Peran seorang Teungku menuntut Murad memancarkan aura sebagai seorang tokoh agama, yang dianggap mampu menuntun dan menyelamatkan warga kampung serta melindungi mereka dari bencana dan marabahaya. Ketergantungan warga klekkkok terhadap seoramng teungku seperti membangun alegori terhadap kebutuhan aceh akan seorang pemimpin yang mampu membawa aceh keluar dari kegelapan, konflik dan kemiskinan. Identitas sebagai Teungku bagi Murad menjadi beban berat dan membuatnya sangat tidak nyaman karena dia memang bukan ahli agama:

Betapa teganya meraka (Imran dan Dahli) mengirimkan aku kemari sebagai seorang teungku palsu hanya untuk menipu orang-orang kampung terbelakang ini. Tidakkah mereka berpikir bahwa aku harus mengkhianati diri sendiri dengan berpura-pura menjadi pandai agama yang disanjung-sanjung? Lalu bagaimana nanti bila aku disuruh mengajar mereka mengaji? Tidakkah mereka tahu aku sendiri tidak terlalu pandai membaca Alqur'an?! (Arafat Nur: 209) 
Perang batin berkecamuk dalam diri Murad. Alih-alih identitas religius sebagai tokoh agama membuat Murad senang dan merasa terhormat, Murad justru merasa menanggung beban berat sekaligus mengenakan topeng kepalsuan. Konstruksi identitas Murad sebagai pelarian berbeda antara kenyataan dan harapan. Pada konteks ini identitas bisa dilihat sebagai suatu proses yang dinamis, yang dipengaruhi kondisi-kondisi ekternal diri, dan bisa terbentuk melalui proses yang disengaja. Identitas lama yang dimiliki Murad pada kutipan di atas bernegosiasi dengan identitas yang diharapkan muncul dari dalam dirinya oleh dua sahabatnya dan juga oleh masyarakat Klekklok. Pertentangan-pertentangan batin ini digambarkan Arafat Nur untuk menegaskan bagaimana Murad harus menghadapi berbagai tekanan dan persoalan rumit selama dalam pelarian.

Namun demikian, realitas peran yang dihadapinya membuat Murad mau tidak mau harus melakukan adapatasi dan mempelajari bagaimana masyarakat Klekklok memandang dan menempatkan seorang Teungku. Salah seorang warga kampung Klekklok menyampaikan peran teungku pada Murad. Bagi orang kampung, peran seorang teungku berkaitan dengan hal-hal religius dan juga supranatural. Warga menganggap ada relasi antara tindakan buruk dengan akibat buruk yang menimpa. Pada konteks inilah identitas seorang Murad yang telah dikenal sebagai teungku dipertaruhkan. Apakah kehadirannya akan membawa kemaslahatan bagi waga dan menjauhkan warga desa dari mara bahaya? Demi menjalankan peran seorang teungku, Murad juga mengalami perubahan identitasnya. Penampilan Murad tidak lagi seperti sebelumnya. Dia mengenakan jubah putih. Identitas yang sebenarnya ditolaknya itu, perlahan memengaruhi kehidupan Murad.

Aku harus memikirkan setiap tindakan yang harus aku lakukan, semua disebabkan jubah putih yang kupakai ini (Arafat Nur, 2016: 217)

Tuntutan sebagai seorang teungku telah membuat Murad akhirnya mengenakan pakaian yang mencirikan identitas teungku. Transformasi identitas yang prosesnya cenderung tidak alamiah, terpaksa, ini dipengaruhi oleh kondisi sosial yang menuntutnya. Woodward memadahkan identitas terbentuk dalam konteks sosial dan melalui pemikiran individu tentang apa yang menghubungkan dirinya dengan dunia luar, yang misalnya berkaitan dengan pakaian yang dikenakan dan tingkah laku yang ditunjukkan (2004:12). Pada konteks ini selain tampilan luar yang ditunjukkan Murad melalui baju yang dia kenakan, tuntunan tingkah laku dan berbagai kompetensi sebagai teungku juga diharapkan oleh masyarakat di kampung Klekklok.

Murad di satu sisi ia harus beradaptasi dengan identitas sebagai teungku dan di sisi lain ia merasa tidak memiliki kemampuan dan bekal untuk menyandang identitas sebagai seorang teungku.

Aku lebih nyaman bila orang-orang ini tidak peduli padaku, membiarkan apa saja yang kulakukan. Gara-gara jubbah dan peci inilah aku menjadi kaku; menjadi manusia lain yang sangat asing, bahkan bagi diriku sendiri. Sialnya aku terpaksa menjalaninya sebagaimana keniscayaan yang dilakukan seorang teungku. Sungguh ini cobaan berat sangat bertentangan dengan diriku yang sebenarnya, sebab aku ini adalah seorang pembunuh! (Arafat Nur, 2016: 2018) 
Selama di kampung Klekklok, Murad dianggap memiliki kemampuan seperti seorang teungku yang sebelumnya pernah tinggal di kampung itu. Dia juga harus bersosialisasi dan membangun peran-peran permberdayaan kultural masyarakat kampung yang terbelakang secara intelektual dan ekonomi. Lebih dari itu seorang teungku diharapkan mampu menangkal sihir, mengobati orang sakit, hingga mengurus hal ihwal metafisik. Harapan masyarakat ini mengindikasikan bahwa identitas teungku sesungguhnya begitu kompleks, berhubungan tidak hanya dengan peran-peran sosial, namun juga kultural dan religius.

Justru di kampung Klekklok yang terpencil itu, Murad lebih bisa melihat realitas masyarakat Aceh di pedalaman yang tak diperhatikan secara pendidikan dan kesejahteraan, namun mereka bisa hidup secara nyaman dan damai. Dia makin terlibat secara sosial dan kultural serta makin menyadari pentingnya peningkatan kehidupan masyarakat bawah yang jauh dari perhatian pemerintah. Keterlibatan Murad terasa mengakar di bawah, dan dirasakan oleh masyarakat. Pada konteks ini Murad dengan identitas barunya memainkan peran-peran sosial budaya keagamaan. Dia tidak lagi berkutat pada hal-hal politik yang banyak mewarnai hidupnya sebelumnya. Hiruk pikuk politik dan aroma konflik seperti menjauh dari hidupnyan selama dia tinggal di Klekklok. Kita bisa melihat konstruksi identitas seorang teungku yang dijalaninya di kampung Klekklok telah membawanya dalam kondisi sosial yang dulu belum pernah dialaminya. Lambat laun dia merasakan kehidupan damai di pedalaman tersebut. Dalam salah satu kutipan di novel "Surga Tanah Merah" Arafat Nur seperti sedang menegaskan harapan itu melalui suara Murad:

Sungguh bila perang dan kekacauan tidak ada di Aceh, rasanya tanah ini benar-benar menjadi Surga, hijau sebagaimana bayanganku masa kanak dulu. Kini semuanya telah berubah menjadi surga merah; bagaimana pun banyaknya darah yang tumpah membasahi tanah ini, aku tetap tidak bisa hidup di tempat lain (Arafat Nur, 2016: 274)

Pernyataan Murad dalam kutipan di hampir bagian akhir novel "Surga Tanah Merah" di atas seakan menegaskan identitasnya sebagai orang Aceh yang mencintai kampung halamannya, yang tak rela sebenarnya tanah Aceh menjadi merah dan amis karena pertumpahan darah. Meskipun Aceh dilanda konflik, Murad tetap ingin tinggal di bumi Aceh. Perjalanan hidupnya yang dinamis dan menyandang berbagai identitas baik sebagai pejuang kemerdekaan, buronan konfik Aceh, politisi partai Merah dan Jingga, hingga seorang teungku makin menegaskan bahwa Aceh adalah bagian dari hidupnya. Identitasnya yang dinamis, berlapis dan terbentuk oleh berbagai faktor eksternal pada dasarnya memetaforakan kompleksitas persoalan Aceh sebagaimana yang dinarasikan oleh Arafat Nur.

Setelah kesepakatan damai terjadi di Aceh, Murad justru berkonflik dengan sesama warga Aceh. Keputusan Murad untuk bersembunyi di luar Aceh mencerminkan upaya menyelamatkan diri dengan cara tinggal di tempat di luar Aceh dan beradaptasi dengan tempat yang secara budaya berbeda dengan budaya tanah kelahirannya. Namun, Arafat Nur menunjukkan melalui novelnya bahwa seorang buronan tak akan bisa melepaskan diri dari bayang-bayang kampung halamannya. Kecintaaan Murad pada kampung halamannya, Aceh, begitu mendarah daging, merasuk dalam jiwanya: "Kerinduan dan kecintaanku terhadap tanah ini Melebihi apapun. Tanah surga tempat jiwaku bersemayam; Tanah Surga merah" (Arafat Nur, 2016:123). Secara fisik Murad berada di luar Aceh untuk bersembunyi dan 
mengasingkan diri, namun secara batin ia sesungguhnya tak pernah pergi dari Aceh, tanah kelahirannya. Ada relasi naluriah antara Murad dengan tanah Rencong yang keindahan alamnya tak tertandingi. Migrasi Murad keluar Aceh adalah kesementaraan (temporal), karena tempatnya pulang tetaplah kampung halamannya sebenarnya (true homeland) yang telah memiliki ikatan batin dengannya. Ia tidak memungkiri kenyataan tanah airnya tak lagi damai, banyak pertikaian dan pertumpahan darah, namun ia mengakui tetap sepenuh hati mencintai Aceh:

Inilah kampung halaman yang kurindukan, Aceh yang kusayang, telah banyak darah tumpah di sini, dan sepertinya akan terus tumpah. Dulu tempat ini surga menawan yang menenangkan, memberitakan berjuta harapan dan impian indah. Sekarang dan sampai kapan pun rasanya aku tidak bisa meninggakan tanah ini, yang kini tetap saja menjadi surga aneh bagiku; ya, tanah surga merah (Arafat Nur, 2016: 121)

Murad berada dalam dialektika masa lalu dan masa kini. Ia membangkitkan masa lalu untuk bernostalgia sekaligus merekonstuksi fragmentasi berbagai harmoni yang pernah ada dan masih dengan baik diingatnya. Surga adalah metafora kampung halamannya yang penuh keindahan; Sementara 'merah' menjadi penanda berbagai tragedi yang terjadi di dalamnya. Gambaran keindahan kampung halaman di masa lalu inilah yang dia oposisikan dengan kondisi sekarang yang penuh teror, rasa ketidaknyamanan, bahkan ancaman pembunuhan.

\section{PERLAWANAN MURAD}

Sebagai orang yang memiliki identitas Aceh Murad mengkritisi dan menginginkan perubahan atas kondisi Aceh yang tak kunjung damai. Murad misalnya mengkritik kebijakan DOM saat orde baru dan juga mengkritik pemerintah dan kondisi Aceh masa kini. Narasi perlawanan yang digaungkan Arafat Nur ini mengingatkan kita pada tokoh GAM, Teungku Hasan diTiro, yang pada 4 Desember 1976 membangkitkan semangat perlawanan dengan mendeklarasikan Negara Aceh Merdeka dan menegaskan bahwa gerakan tersebut merupakan kelanjutan perjuangan rakyat Aceh melawan penjajah; Dia merujuk pada orang-orang Indonesia sebagai penjajah baru yang melakukan penjajahan di Aceh (Abubakar, 2015:55) Tokoh Murad dalam "Tanah Surga Merah" menunjukkan perlawanan ketika melihat tindakan represif aparat militer di Aceh:

Aku memutuskan untuk dan bergabung dengan pejuang atas kemauan sendiri karena tidak tahan dengan sikap dan kelakuan tentara yang begitu kasar dan kejam; mereka kerap membunuh, menculik, menjarah dan memukuli orang-orang seakan hanya itulah tugas utama para tentara yang dianjurkan negara (Arafat Nur, 2016: 33)

Murad menempatkan dirinya beroposisi dengan hegemoni militer. Kritik keras Murad lebih jauh menyasar eksitensi tentara di Aceh yang seakan dikirim untuk hanya mementaskan berbagai adegan horror kekekasan, tanpa misi perdamaian dan mendamaikan. Narasi pembunuhan yang dilakukan oleh aparat mengingatkan kita pada pada orang-orang Aceh yang melawan dan rela mengorbankan nyawanya. Mereka adalah sosok-sosok nyata yang hadir kembali dalam narasi di "Surga Tanah Merah". Narasi sejarah pertumpahan darah dan kematian ini dalam kaitannya dengan eksitensi tokoh-tokoh dalam novel Arafat Nur mengingatkan saya pada pernyataan Hasan di Tiro dalam persembahan naskah drama 
berjudul "Drama Sejarah Orang-Orang Aceh 1973-1978: Drama dalam delapan babak, yang ditulisnya:

Untuk anakku, Karim di Tiro. Untuk mengenang 500.000 para lelaki, perempuan dan anak-anak Aceh yang pemberani-Seperempat dari total populasi-yang meninggal untuk mempertahankan kemerdekaan Aceh dalam perang dengan Belanda dari tahun 1873 sampai 1942. Mereka adalah penulis-penulis, para pemain yang nyata dari drama ini. (1979)

Jika dulu lawan yang dihadapi orang-orang Aceh adalah jelas penjajah Belanda, namun setelah Indonesia merdeka justru yang harus dihadapi adalah orang-orang Indonesia sendiri yang menjelma 'penjajah' baru. Dan melalui Murad, Arafat Nur membangun kritik pada pengelolaan pemerintahan di Aceh yang buruk, menelanjangi sepak terjang para politisi Aceh sebagai politisi-politisi yang tidak mempejuangkan nasib rakyat kecil, dan mengkritisi program-program pemerintah yang semata didesain untuk tujuan keuntungan pribadi dan kelompok (partai) dan masih terlihat tunduk dengan kelompok 'penjajah'.

Kecintaan Murad pada kampung halamannya, Aceh, telah membangun kesadaran dalam dirinya dan membangkitkan daya kritis melihat ketimpangan, kesewenang-wenangan dan tindakan eksploitatif. "Namun, negeri ini sudah dirusak oleh tangan-tangan penjajah dan pemimpin bodoh sehingga bagaimanapun petani bekerja keras, mereka tak akan pernah bisa makmur" (Arafat Nur, 2016: 123) Istilah 'penjajah' digunakan Arafat Nur untuk menggambarkan orang-orang lokal yang berlaku eksploitatif dan cenderung menguasai dan menjadikan rakyat semata sebagai objek. Bagi Arafat Nur, 'penjajah' bukan lagi identitas yang berhubungan dengan penjajah barat dan Jepang yang pernah bercokol di Indonesia, namun juga para elit pusat dan lokal yang bertindak eksploitatif dan melakukan praktikpraktif penyalahgunaan kekuasaan.

Murad muak dengan teman-temannya dulu yang kini menduduki posisi berbagai pucuk pimpinan di partai penguasa. Ketika Murad menemui sahabat lamanya yang bernama Abduh, Murad makin mendapatkan gambaran tentang sepak terjang orang-orang Aceh yang ada di Partai Merah yang tengah berkuasa:

Abduh mengatakan bahwa sikap orang-orang partai merah yang sedang berkuasa ini makin menjadi-jadi dan menjengkelkan sekali, seolah Aceh sudah merdeka dan berada dalam genggaman tangan mereka, dengan dinaungi ramhat Tuhan yang Maha Kuasa. Padahal setiap hari mereka lalu lalang di depan tangsi tentara dan kantor polisi yang bertebaran di mana-mana, dengan tubuh membungkuk dan leher menekuk serupa budak malang di tanah jajahan (Arafat Nur, 2016: 25)

Sikap inferior yang ditunjukkan oleh orang-orang partai merah diumpamakan Arafat Nur sebagai sikap orang-orang yang terjajah. Pengumpamaan ini menunjukkan mental 'inlader' yang pernah menjangkiti orang-orang Indonesia ketika dijajah oleh Belanda. Aceh dianggap belum sepenuhnya 'merdeka', bebas dari hegemoni pusat. Pada konteks kutipan di atas, tentara dan polisi direpresentasikan Arafat Nur sebagai kepanjangan tangan pemerintah (state apparatus), yang dianggap sebagai 'penjajah'. Murad secara berani mengartikulasikan kritik-kritiknya dengan bahasa-bahasa sarkastik dan tajam, termasuk kritik pada teman-teman perjuangan Murad dulu yang sekarang banyak menjadi anggota dewan di Aceh. Pada konteks 
ini, saya sebagai pembaca memiliki kesan atas keberanian Arafat Nur dalam menelanjangi sepak terjang partai dan para politisi partai itu yang brobrok.

Bagi Arafat Nur dalam novelnya, selepas dari cengkeraman kebijakan represif dan eksplotatif pemerintah pusat, rakyat Aceh justu harus menghadap praktik penindasan dan tirani baru dari para penguasa lokal. Kehidupan rakyat Aceh dinilai belum sejahtera. Padahal Aceh kaya sumber daya alam, seperti di bidang migas. Banyak kepentingan asing melalui perusahan-perusahaannya yang mengeksploitasi bumi Aceh. Proyek Blang Lancang LNG misalnya adalah perpaduan kolaborasi dari kepentingan Jakarta, Jepang dan Amerika Serikat. Bahkan kepentingan ekonomi Amerika di Aceh sangat jelas dengan perusahaan Exxon-Mobil (Fortune 2001; The Ecologist 2001, sebagimana dipaparkan dalam Matthews N Davies, 2006). Realitas ini membuka peluang dan potensi bagi elite Aceh dan pemerintah pusat untuk meraih keuntungan pribadi dan kelompok. Dulu para elite pemerintah Aceh itu, ketika mereka masih bergerilya memperjuangkan kedaulatan Aceh mereka menyuarakan kemerdekaan, kebebasan, namun ketika mereka menjabat mereka justru merampas hak-hak warga dan melegitimasi kebijakan pemerintah pusat:

Orang-orang yang dulu berteriak-teriak demi kemerdekaan, demi martabat, dan demi Aceh yang hebat, justru merekalah yang merusaknya. Kekuasaan di tangan mereka bukannya membuat Aceh tambah baik. Aceh masih jauh lebih bagus ketika masih berada di bawah pemerintahan sebelumnya, sekalipun dikuasai orang-orang yang merupakan perpanjangan tangan pemerintah Jakarta (Arafat Nur, 2016: 51)

Orang-orang lokal yang dulu dikenal sebagai pejuang kemerdekaan, setelah menjabat justru makin membuat Aceh tidak mengalami kemajuan berarti. Tindakan dan kebijakan mereka, bagi Arafat Nur, justru lebih buruk dibanding dengan penguasa sebelumnya yang dianggap 'penjajah'. Seringkali memang ketika penjajah sebelumnya angkat kaki, maka tindakan eksploitasi dan diskriminasi banyak dilakukan oleh para elite lokal yang memanfaatkan kesempatan untuk memperkaya diri. Masyarakat Aceh seperti keluar dari cengkraman penjajah lama namun masuk ke perangkap penjajah baru. Arafat Nur menggambarkan:

"Penduduk negeri ini semakin merana saja di bawah kendali orang-orang gunung bodoh yang telah berhasil merebut kekuasaan setelah mereka berdamai dengan pemerintah Indonesia. Melalui Partai Merah, partai lokal yang selalu memenangkan pemilihan umum, mereka menduduki tempat-tempat penting terhormat di pemerintahan, baik sebagai kepala pemerintah, pejabat maupun anggota dewan (Arafat Nur, 2016:60)

Istilah orang-orang gunung digunakan oleh Arafat Nur untuk menggambarkan eks para pejuang atau gerilyawan gerakan Aceh Merdeka yang banyak bermukim di pedalaman dan area pegunungan. Mereka dinilai tak berpendidikan dan berpengetahuan, sehingga ketika mereka menjabat mereka tak mampu menggunakan kekuasaan untuk kemaslahatan rakyat Aceh. Narasi Arafat Nur ini menunjukkan penciptaan hegemoni para elite lokal yang bernaung di bawah Partai Merah. 
Melihat realitas sepak terjang para oknum penguasa lokal Aceh yang menyengsarakan dan memikirkan keuntungan pribadi, Murad tidak hanya melontarkan kritik-kritik tajam, namun juga melakukan 'perlawanan' dengan doa yang menunjukkan betapa kesal ia melihat ulah culas para pejabat: Mereka bersenang-senang ketika keluar Aceh, sementara rakyat Aceh masih sengsara:

Aku tetap menguatkan doaku; semoga Tuhan tetap menyempitkan liang kuburnya, juga kubur para anggota dewan lain, sekalian kuburan gubernur, bupati, walikota, dan pejabat-pejabat tukang korupsi yang suka melacur ke Medan dan Jakarta. Ya Allah, kuakkan lebar-lebar liang neraka agar mereka dapat merasakan kesengsaraan rakyat Aceh yang mereka zalimi selama di dunia (Arafat Nur, 2016:124)

Doa di atas adalah ekspresi yang mengandung kritik sekaligus kekesalan. Murad seakan tak bisa menutupi rasa marahnya terhadap para oknum elite Aceh yang mengeruk keuntungan sendiri dan melupakan nasib rakyat Aceh. Ironis rasanya memang, Murad melintasi batas Aceh untuk keluar karena diburu dan hendak dihabisi, sementara para elite Aceh pergi dari Aceh untuk berpesta pora menikmati hasil korupsi. Sungguh ironis.

Surga Tanah Merah telah secara menarik menggambarkan konstruksi identitas seorang pejuang Aceh, Murad, yang dipengaruhi oleh konstalasi politik dan konflik Aceh serta bagaimana dia melakukan resistensi demi untuk Aceh yang lebih baik. Arafat Nur sesungguhnya melalui novel ini membangun kritik pada Aceh dengan harapan Aceh berlimpah kesejahteraan dan kedamaian. Surga Tanah Merah menarasikan konflik berdarah, pertentangan dan pertikaian antar orang Aceh, serta berbagai persoalan seperti korupsi, ketidakadilan, ketimpangan sosial, untuk menyuarakan Aceh yang lebih baik, terbebas dari belenggu-belenggu konflik horisontal yang menguburkan kedamaian dan terlepas dari kuasa para elite yang menyengsarakan.

\section{DAFTAR RUJUKAN}

Abubakar Muhammad bin. 2015. The Politics of National Integration in Indonesia: An Analysis of The Role of Military in the Province Of Aceh. Lhokseumawe: Unimal Press.

Alfian, Teuku Ibrahim. 2003. "Sastra sebagai Arena Pertarungan Politik". Dalam Sastra Interdisliner: Menyandingkan Sastra dan Disiplin Ilmu Sosial. (Muh. Arif Rokhman, dkk). Yogyakarta: Qalam.

Davies, Matthew N. 2006. Indonesia's War over Aceh: Last stand on Mecca's porch. New York: Routledge

Faruk. 2010. Pengantar Sosiologi Sastra. Yogyakarta: Pustaka Pelajar.

Hall, Stuart. 1996. “Who Needs Identity?”. The Question of Cultural Identity. Ed. Stuart Hall and Paul Du Gay. London/ Thousand Oaks/ New Delhi: Sage Publications.

Nur, Arafat. 2016. Surga Tanah Merah. Jakarta: Gramedia.

Rushdie, Salman. 1992. Imaginary Homelands: Essays and Criticism: 1981-91. London: Granta Books.

Tiro, Tengku Hasan M. Di. 1979. The Drama of Acehnese History 1873-1978: A Play In VIII Acts. Ministry Of Education State Of Aceh. 
Woodward, Kath (Ed). 2004. Questioning Identity: Gender, Race and Nation. New York: Routledge. 